\title{
Unroofed coronary sinus in a patient with neurofibromatosis type 1
}

\author{
Seio coronário sem teto em paciente com neurofibromatose do tipo 1
}

Seno coronario sin techo en paciente con neurofibromatosis de tipo 1

Luciano Pereira Bender', Maria Rita F. Meyer', Rafael Fabiano M. Rosa', Rosana Cardoso M. Rosa ${ }^{3}$, Patrícia Trevisan², Paulo Ricardo G. Zen²

\section{ABSTRACT}

Objective: To report the uncommon association between neurofibromatosis type 1 (NF1) and unroofed coronary sinus.

Case description: Girl with four years and six months old who was hospitalized for heart surgery. The cardiac problem was discovered at four months of life. On physical examination, the patient presented several café-au-lait spots in the trunk and the limbs and freckling of the axillary and groin regions. Her father had similar skin findings, suggesting the NF1 diagnosis. The cardiac evaluation by echocardiography disclosed an atrial septal defect of unroofed coronary sinus type. This cardiac finding was confirmed at surgery. The procedure consisted of the atrial septal defect repair with autologous pericardium.

Comments: NF1 is a common autosomal dominant disorder caused by mutations in the NF1 gene. Among the NF1 findings, congenital heart defects are considered unusual. In the literature review, there was no association between NF1 and unroofed coronary sinus, which is a rare cardiac malformation, characterized by a communication between the coronary sinus and the left atrium, resultant from the partial or total absence of the coronary sinus roof. It represents less than $1 \%$ of atrial septal defect cases. More reports are important to determine if this association is real or merely casual, since NF1 is a common condition.

Key-words: neurofibromatosis 1; cafe-au-lait spots; heart defects, congenital; coronary sinus/abnormalities; heart septal defects, atrial.
RESUMO

Objetivo: Relatar a associação incomum entre neurofibromatose do tipo 1 (NF1) e seio coronário sem teto.

Descrição do caso: Menina de quatro anos e seis meses, hospitalizada para realização de cirurgia cardíaca. O problema cardíaco foi descoberto com quatro meses de vida. No exame físico, a paciente apresentava várias manchas café com leite no tronco e nos membros e efélides axilares e inguinais. O pai possuía alterações de pele semelhantes, sendo possível o diagnóstico de NF1. A avaliação cardíaca por meio do ecocardiograma revelou comunicação interatrial do tipo seio coronário sem teto. Esses achados cardíacos foram confirmados na cirurgia. O procedimento consistiu na reparação do defeito do septo atrial com pericárdio autólogo.

Comentários: A NF1 é uma doença autossômica dominante comum causada por mutações no gene NF1. Dentre os achados da NF1, os defeitos cardíacos congênitos são considerados pouco comuns. $\mathrm{Na}$ revisão da literatura, não houve associação entre a NF1 e o seio coronário sem teto, o qual é uma malformação cardíaca rara caracterizada pela comunicação entre o seio coronário e o átrio esquerdo, resultante da ausência parcial ou total do teto do seio coronário, representando menos de $1 \%$ dos casos de defeito do septo atrial. Mais relatos são importantes para determinar se essa associação é real ou apenas casual, já que a NF1 é uma condição comum.

Palavras-chave: neurofibromatose 1; manchas café com leite; cardiopatias congênitas; seio coronário/anormalidades; comunicação interatrial.

Endereço para correspondência:

Paulo Ricardo G. Zen

Rua Sarmento Leite, 245, sala 403 - Centro

CEP 90050-170 - Porto Alegre/RS

E-mail: paulozen@ufcspa.edu.br

2UFCSPA, Porto Alegre, RS, Brasil

${ }^{3}$ Grupo Hospitalar Conceição, Porto Alegre, RS, Brasil
Fonte financiadora: Coordenação de Aperfeiçoamento de Pessoal de Nível Superior (Capes)

Conflito de interesse: nada a declarar

Recebido em: 8/2/2013

Aprovado em: 2/4/2013 


\section{RESUMEN}

Objetivo: Subrayar la asociación poco común entre neurofibromatosis de tipo 1 (NF1) y seno coronario sin techo.

Descripción del caso: Niña de cuatro años y seis meses, hospitalizada para realización de cirugía cardíaca. Se descubrió el problema cardíaco con cuatro meses de vida. En el examen físico, la paciente presentaba varias manchas café con leche en el tronco y en los miembros y lentigos axilares e inguinales. El padre poseía alteraciones de piel semejantes, siendo posible el diagnóstico de NF1. La evaluación cardiaca mediante ecocardiograma reveló comunicación interatrial de tipo seno coronario sin techo. Esos hallazgos cardiacos fueron confirmados en la cirugía. El procedimiento constituye en la reparación del defecto del septo atrial con pericardio autólogo.

Comentarios: NF1 es una enfermedad autosómica dominante común causada por mutaciones del gene NF1. Entre los hallazgos de NF1, los defectos cardiacos congénitos son considerados poco comunes. En la revisión de la literatura, no hubo asociación entre NF1 y el seno coronario sin techo, que es una malformación cardiaca rara caracterizada por la comunicación entre el seno coronario y el atrio izquierdo, resultante de la ausencia parcial o total del techo del seno coronario, representando menos del $1 \%$ de los casos de defecto del septo atrial. Más relatos son importantes para determinar si esa asociación es real o solamente casual, ya que NF1 es una condición común.
Palabras clave: neurofibromatosis 1; manchas café con leche; cardiopatías congénitas; seno coronario/anormalidades; comunicación interatrial.

\section{Introduction}

Neurofibromatosis type 1 (NF1) (OMIM 162200) $)^{(1)}$ is an autosomal dominant disorder, caused by mutations in the NF1 gene, located in 17q11.2. The incidence is described as $1 / 2,000-7,800$ births $^{(2,3)}$. NF1 is usually diagnosed based on clinical criteria of the National Institute of Health Consensus ${ }^{(4)}$, which assesses the presence of findings such as café-au-lait spots, neurofibromas, freckles in the axillary and inguinal regions, and family history of a first degree relative with NF1. Among the findings of NF1, congenital heart defects are uncommon ${ }^{(5,6)}$.

This study reported the association between NF1 and unroofed coronary sinus, not yet described in the literature.

\section{Case Description}

Black female patient, aged 4 years and 6 months, hospitalized for surgical correction of a heart defect. She was the only daughter of a non-consanguineous couple, aged 27 (mother) and 23 (father). The mother had three other healthy children from two previous marriages. There was no history of congenital heart disease in the family. The mother reported occasional alcohol intake during pregnancy. Syphilis was diagnosed in the 4th month of gestation and treated
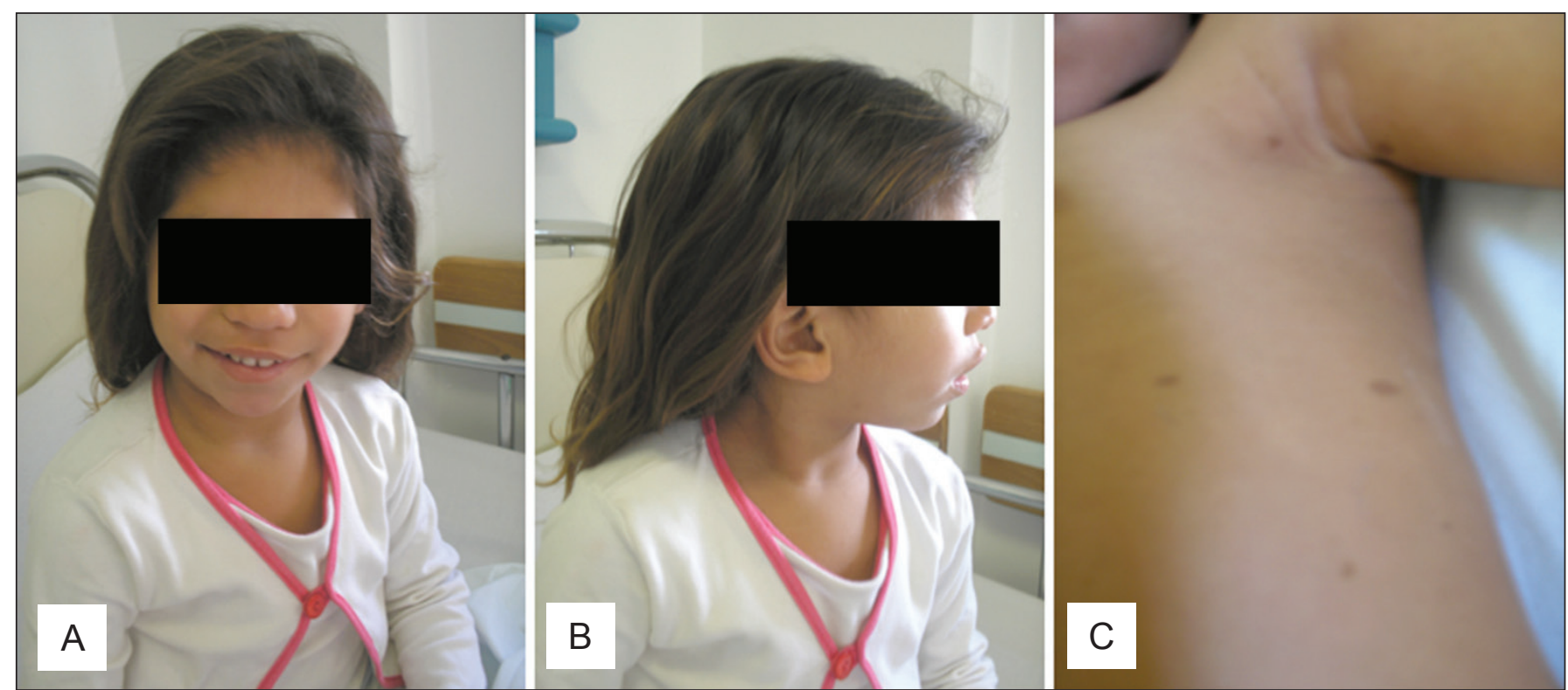

Figure 1 - Patient at 4 years and 6 months (A, B and C). Note especially café-au-lait spots and axillary freckles (C) 
with Penicillin. The patient also had loss of amniotic fluid during pregnancy. The child was born by caesarean section, cephalic presentation, 30 weeks preterm, weighing 2,075g, measuring $42,5 \mathrm{~cm}$, head circumference of $31 \mathrm{~cm}$, and had Apgar scores at 1 and 5 minutes, of 8 and 9 respectively. The child cried immediately after birth and was not cyanotic. The screening test was normal. Congenital heart disease was discovered at 4 months of life. The neuropsychomotor development was normal and there were no behavior problems.

On physical examination, at 4 years and 6 months old, the patient presented weight of $17,500 \mathrm{~g}$ (50-75th percentile), height of $105 \mathrm{~cm}$ (50-75th percentile), and head circumference of $48.5 \mathrm{~cm}$ (2-50th percentile) (anthropometric measures evaluated according the CDC Growth Charts - http://www. cdc.gov/nchs/data/series/sr_11/sr11_246.pdf). The patient was not syndromic but had dysmorphic features that included bilateral epicanthal folds, broad nasal root with bulbous nose, high arcade palate, large mouth with thick lips, pectus carinatum, cubitus valgus, and clinodactyly of fifth fingers. On the skin, there were many (more than six) café-au-lait spots measuring about $2-3 \mathrm{~cm}$ in the trunk and limbs and freckles in the axillary and inguinal regions (Figure 1). Family history revealed that the father had similar skin findings (multiple café-au-lait spots and freckles in the axillary/inguinal regions). This enabled the diagnosis of NF1, which was also confirmed by dermatological evaluation. Ophthalmologic examination was normal. Cardiac evaluation of the child by echocardiography revealed unroofed coronary sinus atrial septal defect. There was no persistence of left superior vena cava. These cardiac findings were confirmed at surgery. The procedure consisted of repair of atrial septal defect with autologous pericardium. Abdominal ultrasonography and spine radiography were normal. The high-resolution karyotype by GTG banding and fluorescence in situ hybridization for 22q11 microdeletion (using the probe TelVysion TM TUPLE 1, Abbott Molecular Inc.) were also normal.

\section{Discussion}

The clinical findings presented by the patient, plus the family history allowed the diagnosis of $\mathrm{NF}^{(4)}$. The child was part of the sample of a study by Rosa $e t a l^{(7)}$, in which, among 204 patients with heart disease, she was the only one $(0.5 \%)$ to present diagnosis of NF1. It is noteworthy that there was no description of NF1 in patients with congenital heart disease, even in studies with large samples ${ }^{(8-12)}$. Perhaps this relates to the fact that NF1 is often diagnosed in late childhood $^{(2)}$, while patients with congenital heart disease are usually diagnosed earlier, due to the severity of their congenital malformations.

Cardiovascular malformations are also uncommon in individuals with NF1. The frequencies described in the literature generally range from 0.4 to $6.4 \%{ }^{(6)}$. Tedesco et $a^{(5)}$ found a higher frequency (27\%) of cardiovascular malformations diagnosed by echocardiography in $48 \mathrm{pa}-$ tients with NF1. Among the heart defects, pulmonary stenosis and coarctation of the aorta were the most common. Conotruncal heart defects, involving the outflow tract and atrioventricular septal defects, apparently presented low association with $\mathrm{NF}{ }^{(5)}$. In the literature review, there was no association between NF1 and unroofed coronary sinus atrial septal defect. Lin $e t$ a $l^{(6)}$ reported unspecified atrial septal defects. Tedesco et al $l^{(5)}$ found two patients with atrial septal defect, both ostium secundum.

Unroofed coronary sinus atrial septal defect is a rare cardiac malformation characterized by communication between the coronary sinus and the left atrium, resulting in partial or total absence of the coronary sinus roof ${ }^{(13-16)}$. This communication represents less than $1 \%$ of atrial septal defects, often from 0.2 to 0.6 cases by 1,000 live births ${ }^{(16)}$. The diagnosis of unroofed coronary sinus became possible after the advent of the echocardiography. Before that, the diagnosis was only made during surgery ${ }^{(14,15)}$. The unroofed coronary sinus is strongly associated with persistent left superior vena cava ${ }^{(13-15)}$.

Despite prenatal exposure to alcohol, the case study did not meet the diagnostic criteria for fetal alcohol syndrome ${ }^{(17)}$. However, it is noteworthy the fact that prenatal exposure to alcohol is also equally associated with an increased risk (approximately $25-50 \%$ ) for a number of cardiac malformations and, although there is no predominance of a type, atrial septal defects are the most common ${ }^{(13,17)}$. In this review, however, there were no reports of alcohol exposure associated with unroofed coronary sinus atrial septal defect.

Although the patient met the diagnostic criteria for NF1 established by the National Institute of Health Consensus ${ }^{(4)}$, she could also have presented a condition that was part of the differential diagnosis of NF1. The condition that most caught the attention was the Legius syndrome (OMIM $611431)^{(1)}$, also an autosomal dominant genetic disease characterized by the presence of café-au-lait spots and freckles in the axillary and inguinal regions, but without neurofibromas. However, individuals with the Legius syndrome normally present variable dysmorphic features, such as hypertelorism, 
macrocephaly, and lipomas, characteristics that were not observed in the patient described. Moreover, unlike NF1, congenital heart defects have not been described in patients with Legius syndrome. Another condition considered in the differential diagnosis of NF1 is the Watson syndrome $\left(\right.$ OMIM 193520) ${ }^{(1)}$. However, this syndrome usually presents with macrocephaly and short stature. Furthermore, the cardiac defect associated to the syndrome is pulmonary valve stenosis. There is still an autosomal dominant condition, whose only clinical manifestations are multiple caféau-lait spots (OMIM 114030) $)^{(1)}$, without freckles in the axillary and inguinal regions. Due to the low likelihood of such conditions in this case, the most likely diagnosis was established as NF1.

\section{References}

1. Online Mendelian Inheritance in Man (OMIM) [homepage on the Internet]. Baltimore e Bethesda: BeMcKusick-Nathans Institute for Genetic Medicine, Johns Hopkins University and National Center for Biotechnology Information, National Library of Medicine [cited 2013 March 13]. Available from: http://www. ncbi.nlm.nih.gov/omim/

2. Darrigo Jr LG, Bonalumi Filho A, D'Alessandro DS, Geller M. Neurofibromatosis type 1 in childhood: review of clinical aspects. Rev Paul Pediatr 2008;26: 176-82.

3. Graziadio C, Lorenzen MB, de Moraes FN, Rosa RF, Zen PR, Raupp $\mathrm{SF}$ et al. Multiple central nervous system hyperintensities in a child with neurofibromatosis type 1. Rev Paul Pediatr 2011;29:694-8.

4. Autoria não referida. Neurofibromatosis. Conference statement. National Institutes of Health Consensus Development Conference. Arch Neurol 1988;45:575-8.

5. Tedesco MA, Di Salvo G, Natale F, Pergola V, Calabrese E, Grassia C et al. The heart in neurofibromatosis type 1: an echocardiographic study. Am Heart J 2002;143:883-8.

6. Lin $\mathrm{AE}$, Birch $\mathrm{PH}$, Korf $\mathrm{BR}$, Tenconi R, Niimura M, Poyhonen $\mathrm{M}$ et al. Cardiovascular malformations and other cardiovascular abnormalities in neurofibromatosis 1. Am J Med Genet 2000;95:108-17.

7. Rosa RF, Pilla CB, Pereira VL, Flores JA, Golendziner E, Koshiyama DB et al. 22q11.2 deletion syndrome in patients admitted to a cardiac pediatric intensive care unit in Brazil. Am J Med Genet A 2008;146A:1655-61.
This report described the unusual association between NF1 and unroofed coronary sinus atrial septal defect. More studies are important to determine whether this association is real of merely casual, since NF1 is a common condition. Perhaps some patients with NF1 or even with prenatal exposure to alcohol, and unspecified atrial septal defect, may present unroofed coronary sinus. However, the probability that NF1 and unroofed coronary sinus happen by chance together is one in $1,000,000,000$.

\section{Acknowledgements}

We are thankful to the Coordination for the Improvement of Higher Education Personnel (Capes) for the scholarship granted.

8. Ferencz C, Rubin JD, McCarter RJ, Boughman JA, Wilson PD, Brenner JI et al. Cardiac and noncardiac malformations: observations in a population-based study. Teratology 1987;35:367-78.

9. Grech V, Gatt M. Syndromes and malformations associated with congenital heart disease in a population-based study. Int J Cardiol 1999;68:151-6.

10. Hanna EJ, Nevin NC, Nelson J. Genetic study of congenital heart defects in Northern Ireland (1974-1978). J Med Genet 1994;31:858-63.

11. Pradat $P$. Noncardiac malformations at major congenital heart defects. Pediatr Cardiol 1997;18:11-8.

12. Amorim LF, Pires CA, Lana AM, Campos AS, Aguiar RA, Tibúrcio JD et al. Presentation of congenital heart disease diagnosed at birth: analysis of 29,770 newborn infants. J Pediatr (Rio J) 2008;84:83-90.

13. Stevenson RE, Hall JG. Human malformations and related anomalies. $2^{\text {nd }}$ ed New York: Oxford University Press; 2006.

14. Ootaki Y, Yamaguchi M, Yoshimura N, Oka S, Yoshida M, Hasegawa T. Unroofed coronary sinus syndrome: diagnosis, classification, and surgical treatment. J Thorac Cardiovasc Surg 2003;126:1655-6.

15. Cannavale G, Higgins CB, Ordovas KG. Unroofing the diagnosis. Int J Cardiovasc Imaging 2010;26:841-2.

16. Chaturvedi A, Dubinsky TJ, Maki JH. MR findings of a rare defect, coronary sinus ASD. Int J Cardiovasc Imaging 2012;28:429-30.

17. Cassidy SB, Allanson JE. Management of genetic syndromes. $3^{\text {rd }}$ ed. New Jersey: John Wiley \& Sons; 2010. 